Research Article

\title{
Knowledge and attitude of universal precaution among nursing staff in a tertiary hospital of Manipur
}

\author{
Susmita Chaudhuri ${ }^{1 *}$, Omkar Prasad Baidya ${ }^{2}$, T. Gambhir Singh ${ }^{3}$
}

\author{
${ }^{1}$ Department Community Medicine, ESI PGIMSR \& ESIC Medical College, Joka, West Bengal, India \\ ${ }^{2}$ Department Physiology, I-Care Institute of Medical Sciences, Haldia, West Bengal, India \\ ${ }^{3}$ Department Community Medicine, Regional Institute of Medical Sciences, Imphal, India
}

Received: 23 November 2015

Accepted: 18 December 2015

\section{*Correspondence:}

Dr. Susmita Chaudhuri,

E-mail: schaudhuri1986@gmail.com

Copyright: ( ) the author(s), publisher and licensee Medip Academy. This is an open-access article distributed under the terms of the Creative Commons Attribution Non-Commercial License, which permits unrestricted non-commercial use, distribution, and reproduction in any medium, provided the original work is properly cited.

\section{ABSTRACT}

Background: Health workers are exposed to blood and other body fluids in the course of their work. Successful implementation of universal precaution can effectively control these infections in health care setting. The objectives were to assess the knowledge \& attitude of universal precautions among nurses in a tertiary health centre of Manipur. Methods: A cross-sectional study was conducted among the nursing staffs in a tertiary health care centre of Manipur during October 2011 to September 2013. Respondents were purposively selected and data were collected using structured questionnaire. Descriptive statistics like percentage was used to describe the findings.

Results: Total respondents were 446 nurses. Response rate was $98 \%$. Majority of the nurses i.e. $86.3 \%$ were aware of universal precaution. $61.8 \%$ of the nurses mentioned wearing gloves for contact with body fluid, non-intact skin and mucous membrane as a measure that constituted universal precaution. More than half of them knew about the personal protective equipment use and the importance of hand washing. Around 6 in 100 nurses knew that recapping should be avoided. Only $1.8 \%$ of the nurses knew about proper sharp disposal. Little was known about biomedical waste management and disposal (9.9\%). $81.5 \%$ answered correctly that the aim of universal precaution is to prevent mutual transfer of infection between patients and health care workers. Eight in ten nurses (79.5\%) knew correctly that all patients were a source of potentially infectious blood and body fluids. Majority of the nurses agreed that universal precaution should be applied in institutional practice (77.8\%).

Conclusions: Awareness and attitude were favourable. But detailed knowledge about universal precaution was little. Training of the health care workers, proper equipment supply, posters displaying guidelines and proper hospital policy of patient load management would significantly help both quantitatively and qualitatively for effective implementation of universal precaution in this premier health care institution of Manipur.

Keywords: Universal precaution, Knowledge, Attitude

\section{INTRODUCTION}

Health workers are exposed to blood and other body fluids during their work resulting in higher risk of infection with blood-borne viruses like human immunodeficiency virus (HIV), hepatitis B virus (HBV) and hepatitis $\mathrm{C}$ virus (HCV). Chances of risk are strongly influenced by the prevalence of disease in patient population and the nature and frequency of exposures.
Needle-stick or other sharps injury, splash of blood or other body fluids into the eyes, nose or mouth or blood contact with non-intact skin are the commonest modes of occupational exposure to blood. ${ }^{1}$ These occupational exposure to blood-borne pathogen has adversely affect the health workforce especially in resource poor countries. ${ }^{2}$ Most blood exposures in health settings are preventable. Implementation of universal precaution is one of the most important strategies to protect health 
workers. ${ }^{1}$ Universal precaution (UP) is defined as a method of infection control recommended by the Centre for Disease Control (CDC) in which all human blood, certain body fluids, as well as fresh tissues and cells of human origin are handled as if they are known to be infected with HIV, HBV and or other blood-borne pathogens. ${ }^{3}$ It is not feasible, effective or cost-effective to test all patients for all pathogens beforehand to identify them as a potentially infective person, only nature of procedure can decide what precautions to be applied. ${ }^{1}$

Universal precaution awareness has not been pronounced among health care workers, particularly in developing countries. In India, very few studies, with varying focus, have been conducted in this field. Therefore, this study is conducted to assess the knowledge \& attitude of Universal Precautions among nurses in the course of their duties at a tertiary health centre.

\section{METHODS}

A cross-sectional study was conducted among the nursing staffs in a tertiary health care centre of Manipur during October 2011 to September 2013. In this study, respondents were purposively selected and data were collected using structured questionnaire. The questionnaire was divided into 3 sections which included questions on baseline characteristics, knowledge \& attitude of universal precaution. Those who refused to participate and who could not be contacted even after 3 successive visits were excluded from the study. After obtaining the permission from the respective Head of the departments, nurses working at RIMS, at the time of their duty, were approached. They were initially informed about the study, and those who consented were given a questionnaire. An appointment for 30 minutes was made with each of the individual respondent to answer questionnaire and any doubt regarding the topic and questions was clarified. Data so collected were checked for consistency and completeness and fitted in data base software. Descriptive statistics like percentage was used to describe the findings using SPSS version 16. The study was approved by Institutional Ethics Committee, RIMS, Imphal. Informed consent from the study participants was taken. Confidentiality of the respondents was maintained.

\section{RESULTS}

Total respondents were 446 nurses. Response rate was $98 \%$ excluding 6 respondents who did not give consent \& 4 of them who could not be contacted. Among them, 119 nurses were 40 yrs and above $(30 \%)$. All nurses were females 253 respondents had job experience of $<5$ years, i.e. $56.7 \%$ [Table 1].

In our study, majority of the respondents were aware of universal precaution i.e. $385(86.3 \%)$. But when asked about the measures that constituted universal precaution, 238 respondents out of $385(61.8 \%)$ knew that wearing glove for contact with body fluid was a measure. Wearing mask, eye protection and gown during blood and other body fluid exposure was also mentioned by $59.7 \%$ of them. Hand washing after any direct contact with patient was known to $50.1 \%$ of them.

Table 1: Baseline characteristics ( $\mathrm{N}=446)$.

\begin{tabular}{|lcl|}
\hline Characteristics & Number & Percentage \\
\hline Age ( years) & & \\
\hline $20-24$ & 58 & 13.0 \\
\hline $25-29$ & 82 & 18.4 \\
\hline $30-34$ & 119 & 26.7 \\
\hline $35-39$ & 53 & 11.9 \\
\hline 40 and above & 134 & 30.0 \\
\hline Gender & & \\
\hline Male & 0 & 0 \\
\hline Female & 446 & 100 \\
\hline Job experience (years) & \\
\hline$<5$ & 253 & 56.7 \\
\hline$\geq 5$ & 193 & 43.3 \\
\hline
\end{tabular}

Table 2: Participants' responses to the measures that constituted universal precaution $(\mathrm{N}=385)$.

\begin{tabular}{|llc|}
\hline Responses & n & $\%$ \\
\hline $\begin{array}{l}\text { Hand washing after any direct contact } \\
\text { with patients }\end{array}$ & 193 & 50.1 \\
\hline $\begin{array}{l}\text { Preventing two-handed recapping of } \\
\text { needles }\end{array}$ & 24 & 6.2 \\
\hline $\begin{array}{l}\text { Safe collection and disposal of needles } \\
\text { and sharps }\end{array}$ & 7 & 1.8 \\
\hline $\begin{array}{l}\text { Wearing gloves for contact with body } \\
\text { fluids, non-intact skin and mucous } \\
\text { membranes }\end{array}$ & 238 & 61.8 \\
\hline $\begin{array}{l}\text { Wearing a mask, eye protection and a } \\
\text { gown if blood or other body fluids might } \\
\text { splash }\end{array}$ & 230 & 59.7 \\
\hline $\begin{array}{l}\text { Covering all cuts and abrasions with a } \\
\text { waterproof dressing }\end{array}$ & 0 & 0 \\
\hline $\begin{array}{l}\text { Promptly and carefully cleaning up spills } \\
\text { of blood and other body fluids }\end{array}$ & 40 & 10.4 \\
\hline $\begin{array}{l}\text { Safe system for waste management and } \\
\text { disposal }\end{array}$ & 38 & 9.9 \\
\hline
\end{tabular}

Multiple answers allowed

Table 3: Participants' response to knowledge questions $(\mathrm{N}=385)$.

\begin{tabular}{|lll|} 
Responses & n & $\%$ \\
\hline $\begin{array}{l}\text { All patients should be considered as a } \\
\text { source of potentially infectious }\end{array}$ & 306 & 79.5 \\
\hline $\begin{array}{l}\text { Aim of universal precaution is to prevent } \\
\text { mutual transfer of infection between } \\
\text { patients and health care workers }\end{array}$ & 314 & 81.5 \\
\hline
\end{tabular}

Majority of the respondents, $81.5 \%$ said that the main aim of universal precaution was to protect both the 
patients and health care workers. Around 8 in 10 respondents considered all patients as a source of potentially infectious diseases [Table 3].

In this present study, $91.4 \%$ agreed that they were at risk of infection in workplace and majority of the nurses agreed that universal precaution should be applied in institutional practice $(77.8 \%)$. They also agreed that they had professional duty to care for patients with blood and body fluid infection [Table 4].
Few respondents were aware about recapping techniques $(6.2 \%)$ and safe collection and disposal of needle sharp $(1.8 \%)$. Out of all the respondents, 40 told about promptly cleaning of spills of blood or other fluids. Biomedical waste management was known to $9.9 \%$ of the respondents. Nobody knew that the cuts and abrasions had to be covered [Table 2].

Table 4: Participants attitude towards universal precaution $(\mathrm{N}=446)$.

\begin{tabular}{|llllll|}
\hline Statement & Strongly agree & Agree & Neutral & Disagree & Strongly disagree \\
\hline $\begin{array}{l}\text { Universal precaution should be regularly } \\
\text { applied in institutional practice }\end{array}$ & $171(38.3)$ & $176(39.5)$ & $43(09.6)$ & $55(12.3)$ & $1(0.2)$ \\
\hline Always at risk of infection in workplace & $274(61.4)$ & $134(30.0)$ & $27(06.1)$ & $11(02.5)$ & $0(0.0)$ \\
\hline $\begin{array}{l}\text { Professional duty to care for patients with } \\
\text { blood and body fluid infection }\end{array}$ & $118(26.5)$ & $222(49.8)$ & $16(03.6)$ & $72(16.1)$ & $18(04.0)$ \\
\hline
\end{tabular}

\section{DISCUSSION}

In this present study, $86.3 \%$ of the nurses were aware of universal precaution which was similar with study conducted by Hesse A and Irda Sari Y et al where $92 \%$ nurses had knowledge regarding UP. ${ }^{4,5}$ Findings are again in concurrence with Admina et al, Danchaivijtr et al. ${ }^{6,7}$ But when asked about the measures that constituted Universal Precaution, little more than half of the respondents knew about wearing glove, mask, eye protection and gown for contact with body fluid, nonintact skin and mucous membrane. This finding was similar with a study conducted by Mukharjee $\mathrm{S}$ et al where correct knowledge was observed regarding the use of gloves and aprons, but knowledge related to the use of goggles was found to be poor. ${ }^{8}$ Hand washing after any direct contact with patient was known to half of them. This was in contrast with the findings of Mukharjee et al, Chopra $\mathrm{S}$ et al, where almost everyone were aware that proper hand washing was necessary for minimising the chances of spread of micro-organisms. ${ }^{8,9}$ The reason of this low awareness might be because of the ignorance of the proper hand-washing technique that prompted the respondents to answer 'no'. Our study observed little knowledge about recapping \& safe collection and disposal of needle sharps. This was in contrast with a study conducted in Kolkata where respondents were aware of the policy to never bend or recap used needles \& had correct knowledge of safe disposal of sharp instruments. ${ }^{8,9}$ In our study only 1 in 10 nurses told about the cleaning of spills of blood or other fluids \& Biomedical Waste Management. Nobody knew that the cuts and abrasions had to be covered. This finding was in contrast with Abdulraheem et al where medical waste management was known to more than half of the respondents. ${ }^{10}$ Inadequate knowledge regarding these measures could be explained by less exposure to training $\&$ improper hospital policy. Our study finding shows that
8 in 10 participants knew about the main aim of universal precaution as to protect both the patients and health care workers which was more than a study finding where about one third of respondents knew it correctly. ${ }^{10}$ The present study results may be explained by social desirability bias as all the respondents over-reported the duty of a health care worker is to protect both the patients and themselves. Majority of the respondents were aware that all patients should be considered infectious which was similar with Kurien $M$ et al, Johnson OE et al. ${ }^{6,11}$ In this present study, 9 in 10 nurses agreed that they were at risk of infection in workplace, which was similar to the study finding of Irda Sari Y et al. ${ }^{5}$ Majority of the nurses agreed that universal precaution should be applied in institutional practice which was similar with another study finding but was higher than the response got from a study by Kurien $\mathrm{M}$ et al. ${ }^{4,11}$ In another study conducted by Chopra $\mathrm{S}$ et al where majority of the nurses agreed that they had professional duty to care for patients with blood and body fluid infection which was comparable with the present study finding. ${ }^{9}$

\section{CONCLUSION}

The present study highlighted the knowledge \& attitude of universal precaution among the nurses in a tertiary health care centre of Manipur. The findings show that almost nine in ten of the participants were aware of universal precaution. But when asked in details, only few of them had complete knowledge. Majority of the participants had favourable attitude as more than two third of them agreed that universal precaution should be applied in institutional practice. Training of the health care workers, posters displaying guidelines and proper hospital policy would significantly help both quantitatively and qualitatively in effective implementation of universal precaution in this premier health care institution of Manipur. 


\section{ACKNOWLEDGEMENT}

We acknowledge all the nurses, head of the department of respective department for their kind permission \& active participation.

Funding: No funding sources Conflict of interest: None declared

Ethical approval: The study was approved by the Institutional Ethics Committee

\section{REFERENCES}

1. Aide-Memoire. Secretariat of the Safe Injection Global Network. Department of Essential Health Technologies. World Health Organization 2003. 20 Avenue Appia, 1211 Geneva 27, Switzerland. Available at: http://www.who.int/occupational_health/activities/1 am_hcw.pdf. Accessed on Jan 30, 2012.

2. Prüss-Ustün A, Rapiti E, Hutin Y. Estimation of the global burden of disease attributable to contaminated sharps injuries among health-care workers. Am J Ind Med. 2005;48(6):482-90.

3. Segen's Medical Dictionary. Available at: URL: http://www.medicaldictionary.thefreedictionary.co. Accessed August 28, 2011.

4. Hesse A, Adu-Aryee NA, Entsua-Mensah K, Wu L. Knowledge, attitude and practice universal basic precautions by medical personnel in a teaching hospital. Ghana Med J. 2006;40(2):61-4.

5. Irda SY, Ibrahim K, Haroen H, Afriandi I, Sunjaya DK, Hinduan ZR, et al. Knowledge, attitude and perceived adherence with universal precautions among health care workers in the obstetrics and gynaecology department of an Indonesian teaching hospital. Int J Infect Control. 2011;7(4).

6. Johnson OE, Asuzu MC, Adebiyi AO. Knowledge and practice of universal precaution among professionals in public and private health facilities in UYO, Southern Nigeria-A comparative study. Ibom Medical Journal. 2012;5(1):9-19.

7. Danchaivijitr S, Tantiwatanapaiboon Y, Chokloikaew S, Tanqtrakool T, Suttisanon L, Chitreechuer L. Universal precautions: knowledge, compliance and attitudes of doctors and nurses in Thailand. $\mathbf{J}$ Med Assoc Thai. 1995;78 Suppl 2:S112-7.

8. Mukherjee S, Bhattacharyya A, SharmaSarkar B, Goswami DN, Ghosh S, Samanta A. Knowledge and practice of standard precautions and awareness regarding post-exposure prophylaxis for HIV among interns of a medical college in West Bengal, India. Oman Med J. 2013;28(2):141-5.

9. Chopra S, Walia I, Verma P, Vati J. Knowledge and practices related to compliance with universal precautions: A study among staff nurses of PGIMER, Chandigarh. Nursing and Midwifery Research Journal. 2008;4(2):59-67.

10. Abdulraheem IS, Amodu MO, Saka MJ, Bolarinwa OA, Uthman MMB. Knowledge, awareness and compliance with standard precaution among health workers in North-eastern Nigera. J Community Med Health Edu. 2012;2(3).

11. Kurien M, Thomas K, Ahuja RC, Patel A, Shyla PR, Wig N, et al. Screening for HIV infection by health professionals in India. Natl Med J India. 2007;20(2):59-66.

Cite this article as: Chaudhuri S, Baidya OP, Gambhir Singh T. Knowledge and attitude of universal precaution among nursing staff in a tertiary hospital of Manipur. Int J Community Med Public Health 2016;3:451-4 